\title{
The Effect of Problem-Based Learning Strategy on Developing Critical Thinking Skills
}

\author{
Raghad Alsarayreh, Al-Balqa' Applied University (BAU), Karak University College, Department of Educational \\ and Social Studies, Ragad.Sarayreh@bau.edu.jo, ORCID ID: https://orcid.org/0000-0003-0258-863X
}

\begin{abstract}
This study seeks to investigate the effect of Problem-based Learning (PBL) strategy on developing the critical thinking skills of students in middle schools in a science subject. The design of this study involves a quasi-experimental design in which pre and post-tests were used to examine the development of the critical thinking skills of students. Forty students were randomly selected from a high school in Al-Mazar Al-Janoubi district in Karak governorate, Jordan for the school year 2019-2020. The students were divided into two groups (controlled and experimental) in which the students in the controlled group does not receive instruction, unlike the experimental group which receives instruction concerning (PBL) The results showed that there was a statistically significant difference in the tests' scores before and after the intervention. The researcher found that PBL has an effective role in improving the critical thinking skills of the students based on the result of the mean analysis, standard deviation, and t-test.
\end{abstract}

Keywords: Problem-Solving, Critical Thinking, Strategy, Science. Received: 04.12.2020 Accepted: 10.01 .2021 Published: 04.02.2021

\section{INTRODUCTION}

Science education is one of the important issues that arouse the interest and thinking of researchers and those interested in the field of science education at local, regional, and international levels. This is due to the importance of science courses in educating learners; these courses would help in completing students' cognitive, sentimental, and skill development and the various aspects of their personality [1]. In this regard, [2], [3] state that the traditional teaching methods and approaches suffer from deficiencies and do not encourage learners to be creative, nor do they keep pace with the current scientific and technological development. They also indicate the importance to change or develop the traditional methods of teaching so students can learn by themselves to benefit from what they learn. This leads to the transformation of the role of teachers to mentors in which their role is limited to provide advice and guidance.

There is no doubt that every teacher strives to bring his students to the maximum degree of understanding and comprehension that enables them to face the problems and situations of life with intelligence and wisdom, looking for modern approaches and methods that achieve the desired goals of the learning process; because there are many problems that require solutions and interpretation. Therefore, students need to receive training methods on how to solve their problems or at least simplifying their problems [4], [2], [5]. Thinking and actions of the mind are among the effective tools in dealing with problems, overcoming and simplifying them, so we have to develop students' thinking skills using the appropriate methods strategies [4],[6].

According to the framework of constructivism theory and the intellectual principles that contain organizing effective learning; Many studies were conducted to test the effectiveness and impact of strategies based on constructivist philosophy to improve students' level in various investigations, and among these strategies is the problem-based learning strategy that some studies have revealed its effectiveness in developing achievement and some types of thinking [7], [4], [8]. A study by [7] indicated that problem-based learning can enhance creative thinking skills in Indonesian vocational high school students, and [4] study indicated that teachers use a problem-based learning approach in biology classes to enhance the critical and creative thinking skills of students in their sophomore year in high schools in the Philippines, besides, the [8] study, which confirmed that the problem-based learning model affected students' critical thinking skills and learning outcomes for eleventh-grade students in the Social Sciences program.

Despite the many strategies used for problem-solving, the problem-based learning strategy is said to be more effective in achieving the desired goals. This strategy proposes three basic stages: tasks, cooperating 
groups, and participation, as this strategy is distinguished by providing the content as educational problems or tasks that are thought stimulate, reflect the basic concepts, and work to give students self-confidence and the ability to think [9]. [10] indicates that by 2020, information may double every 35 days, but in science and technology it may double twice every 20 months; from here the main goal of modern scientific education has become the development of thinking skills in general, and scientific thinking skills in particular, and it has become imperative for those in charge of the educational process to pay attention to teaching and developing the skills of critical, creative, logical and scientific thinking [11], [12].

Critical thinking is of great importance in the field of science education in particular, as the nature of science includes a wide range of mental processes and habits required by scientific activities and investigations, such as basic science processes (observation, classification, measurement, use of numbers, forecasting and inference) and integrated science operations (data collection, formulating hypotheses, controlling variables, experimenting, interpreting, and generalizing). Science teaching also includes conducting structured scientific investigations and solving problems [11]). The aforementioned processes are consistent with critical thinking in which they include conceiving, analyzing, synthesizing, and evaluating the information that is generated through observation, experience, thinking, or communication [13]. Therefore, science education is a fertile field for the development of critical thinking because of the nature of science that excites thinking and challenges the mind, and because of its natural and vital phenomena and events.

The previous literature indicates that a problem-based learning strategy can raise the students' level of critical thinking, as indicated by previous studies such as [6], [2], [8], [4].

The reality of science education in Jordan indicates the low level of students' achievement in scientific subjects, their low acquisition of scientific concepts, and their low practices in scientific thinking skills in general. The studies of the National Center for Human Development indicated that the level of Jordanian students on international science and mathematics tests was lower than the international student performance [11]. Perhaps one of the most prominent factors that could have led to such results is the teaching methods used, which focus on rote memorization, indoctrination, and neglect of students' intellectual and creative abilities. Therefore, this study examines the effect of the problem-based learning strategy (PBL) on critical thinking skills in the biology course of high school students. This study is based on a curriculum that was adapted for biology education using PBL. The present study seeks to provide an answer to the following main question:

Does the PBL strategy have a significant effect on the critical thinking of biology students in high schools?

\section{Problem-Based Learning (PBL)}

Problem-based learning strategy is an educational situation in which the student faces a real and realistic problem, and proceeds to solve it according to specific stages by using research, survey, and logical thinking processes until he solves the problem [14]. The PBL strategy is considered one of the models for constructivist learning. The theory of constructivist learning indicates that learners can construct their own knowledge [15]. PBL strategy provides an opportunity for students to find solutions to complex problems [16].

PBL was first adopted in 1969 by Howard Barrows at McMaster University College of Medicine Canada [17], [8]. After that, it was adopted in the sector of health to find solutions to problems, then PBL models were adopted in the schools to enhance the results of learning; currently, the PBL strategy is widely used [8].

Three phases are involved in the concept of PBL strategy: disclosing scenarios of problem, seeking information, and discussing and applying new knowledge to the problems [18]. According to [19], PBL is defined as a type of learning that helps students understand what they are learning and structure meaning for it. It also develops confidence in the students' ability to solve problems. [8] defined PBL as "a learning model using authentic problems as a context for students in solving a problem and thinking critically to get the knowledge and to learn making decisions". follows:

A problem-based learning strategy has several characteristics and has been summarized by [9] as

1- The focus of teaching with this strategy depends on the skill of problem design, in a way that allows free and open research.

2- This strategy helps to develop the concept of self-learning, and it also develops many social skills, such as communicating with others, respecting their opinions, and listening to them. 
3- Cooperation is a fundamental principle in this type of learning, as students discuss it, learn together and help each other in obtaining an understanding of what they are learning, and then it is applied.

4- The teacher's role in this model is limited to directing and guiding the learning process.

[12], [8] stated that the PBL strategy consists of five basic stages that begin with guiding the teacher towards the situation and end with presenting the student's work, production, and analysis as follows:

The first step: directing the student towards the problem, where the teacher determines the objectives of the lesson, describes the required mechanisms and motivates the students to engage in the activity of solving the chosen problem.

The second step: organizing the lesson for the students. In this step, students help the teacher in identifying the lesson tasks related to the problem.

The third step: group research assistance, where the teacher encourages students to gather appropriate information, conduct experiments, and seek explanations and solutions.

The fourth step: results and outputs, this helps the teacher and student to plan and prepare these outcomes.

The fifth step: analyze and evaluate the problem-solving process, in which the teacher helps students reflect on their research, surveys, and the processes they used.

At these points, mentoring teachers is necessary to make the learning consistent with the plan and components of this strategy that are tasks, cooperative groups, and sharing [12].

\section{Critical Thinking}

Education is the most important tool to enhance the efficiency of human resources. Educators should take steps to adjust education to meet the needs of the day [20]. In modern education, critical thinking has become an important title of all educators who are interested in teaching their students how to think to prepare them in a challenging world [18]. Critical thinking skills need to be developed in education because of four reasons. Firstly, it enables learners to value others as a form of moral education. Secondly, to prepare students to grow up, they should understand themselves through self-sufficiency and self-direction. Thirdly, it is the primary objective of learning certain subjects such as mathematics, science, literature, history, etc. Fourthly, it is used to confirm the precision of good thinking, analysis, and deliberation in life [5]. According to [21], theorists, and specialists in the domain of learning theories have offered various definitions to explain the essence of critical thinking.

Critical thinking definitions concentrated on describing it as logical and reflexive thinking to determine what to do or believe; differentiating between better thinking aimed toward implementing versus clarifying a target [18]. [5] mentions that critical thinking is a tool to help students learn independently by conducting interpretation, investigation, and evaluation to determine appropriate and inappropriate. [6] defines it as a tool aimed at making rational choices on what to do and to believe. [22] added that critical thinking is the updating of knowledge, distinguish differences, defining relationships between cause and effect, having ideas from examples, and assessing information about the meaning of fact, negative or positive effects. Critical thinking needs learners' skills and experience. Therefore, learning through the use of the PBL strategy provides learners with the opportunity to develop their critical thinking abilities [23].

\section{Problem-Based Learning and Critical Thinking}

To stimulate teaching and learning, instructors may use the PBL system [24]. Based on [25] that problemsolving, problem analysis, or problem-based learning are strategies viable with skills of critical thinking due to its focus on techniques for science, cooperative approaches, and scientific research. [26] states that PBL techniques affect the critical thinking abilities of senior high school biology students in Malang. [27] reveals that the PBL model enhances the critical thinking of science students in fourth-grade elementary school. There was a low level of a significant relationship between the disposition of critical thinking and problemsolving skills of students in the [28] study.

The development of critical thinking is more likely to exist by using the PBL model because students are more involved in their learning. In this model, students are engaged in debate and questions focused on specific issues, therefore, students actively build their information. PBL fosters students' critical thinking abilities optimally. The attitude of curiosity and the capacity to think objectively, independently, critically, and analytically can be handled by PBL both individually and in groups [29], [8]. [20] states that the pre-test and post-test scores produced a noticeable improvement in the performance of their skills. PBL has high essence 
motivation, has an effect on the task, improves the ability to think, has self-regulated and meta-cognitive learning.

\section{METHODS AND MATERIALS}

This study used the quasi-experimental design; in which two groups are involved (experimental and controlled). The sample of this study includes 40 female students randomly selected from a high school in AlMazar Al-Janoubi district in Karak governorate. The students have been into two intact groups from two classes of students of the tenth grade in Mu'tah Secondary School for Girls. The table below shows the distribution of students according to their groups.

Table 1. Distribution of the study sample

\begin{tabular}{|l|l|l|}
\hline School & The Group & $\begin{array}{l}\text { Number of } \\
\text { female students }\end{array}$ \\
\hline $\begin{array}{l}\text { Mut'ah Secondary } \\
\text { School for Girls }\end{array}$ & Experimental & (20) students (A) \\
\cline { 2 - 3 } & Controller & (20) students (B) \\
\hline Total & \multicolumn{2}{|c|}{ 40 students } \\
\hline
\end{tabular}

\section{Materials of Study}

The materials used in this study were the authentic materials of the first three chapters (genetics, traits inheritance in humans, electric current) from the students' science subject book for the academic year 20192020. The researcher formulated the behavioral objectives to build the test, which included (30) behavioral objectives distributed over the six levels, based on Bloom's classification (knowledge, understanding, application, analysis, synthesis, and evaluation). Twenty teaching lessons related to PBL were prepared by the researcher for each group (experimental and control) at the rate of (3) lessons per week. The controlled group did not receive any instructions concerning PBL, while the experimental group have been trained and instructed on how to use such a strategy.

The researcher prepared a test that measures the development of critical thinking skills with five dimensions: Inference, Recognition Assumption, Deduction, Interpretation, and Evaluation of Arguments. For this purpose, the researcher prepared (25) test items of the multiple-choice type based on the literature review.

\section{Experiment Application Procedures}

Before starting the experiment, the researcher checked the homogeneity between the participants before the commencement of the experiment (see table 2).

Table 2. Mean scores of the participants in the pre-test

\begin{tabular}{|l|l|l|l|l|l|l|}
\hline Variable & Group & $\mathbf{N}$ & $\mathbf{M}$ & St.d & $\mathbf{T}$ & Sig \\
& & & & & & \\
\hline \multirow{2}{*}{ Achieve } & Exper. & 20 & 17.25 & 1.80 & 1.481 & 0.147 \\
\cline { 2 - 7 } & contol & 20 & 16.35 & 2.03 & & \\
\hline
\end{tabular}

Table (2) shows that the mean score of the experimental sample was (17.25), while the mean score of the control sample was (16.35), and the calculated value of T was (1.481). This shows no difference between both groups and confirmed that they are homogeneous. After checking the homogeneity of the two groups, the researcher did the following:

1- It was agreed with the school director that the researcher would teach the science subject herself for the tenth grade. 
2- The researcher started teaching the experimental group based on the problem-based learning strategy and the control group studied according to the traditional method in the period between 10/10/2019 - 1/8/2020. 3 - The researcher applied the instructional plans prepared based on the problem-based learning strategy on the students of the experimental group.

4- The test was applied to two survey samples, the first of which was from the tenth-grade students in the AlJa fari Comprehensive Vocational Secondary School for Girls, and the number reached (15) students. The time required for the test and the clarity of its items were determined. As for the second sample, it was from AlTaiba Secondary School for Girls, and there were (13) students, where the psychometric characteristics were determined and the validity and reliability of the test were known.

5- After completing the teaching of the specific subject, the students of the two groups were informed that there will be an exam that will include the first three semesters of the science subject studied during the second semester, and the critical thinking skills test was applied on the two research groups on 12/1/2020; after completing the test, the researcher corrected the answer sheets, where was given one score of the correct answer and a score of 0 for the wrong answer.

\section{RESULTS AND DISCUSSION}

To answer the study question, the researcher calculated the mean and the value of (T) using the independent sample T-test to compare the means of the experimental group students and the means of the control group students in the critical thinking development test (see table 3).

Table 3. results of (T) test for the scores of the students of the two groups in the test of developing critical thinking skills

\begin{tabular}{|l|l|l|l|l|l|}
\hline Group & N & M & St.d & T & Sig \\
& & & & & \\
\hline Exper. & 2 & 20.85 & $\begin{array}{l}1.9 \\
8\end{array}$ & 5.781 & 0.000 \\
& 0 & & $\begin{array}{l}1.7 \\
9\end{array}$ & & \\
\hline contol & 2 & 17.40 & & \\
& 0 & & 9
\end{tabular}

The above table shows that the mean of the scores of the students of the experimental group is (20.85) with a standard deviation (1.98), while the mean of the scores of the students of the control group is (17.40) with a standard deviation (1.79). The table also showed that the calculated value of (t) (5.781) is greater than the tabular value of (t) (2.457) at the degree of freedom (38) and the level of significance (0.01), which confirms the existence of a significant difference between the mean of groups in favor of the experimental group. This result is evidence of the superiority of the experimental group students who were taught based on the problem-based learning strategy over the control group students who were taught on the traditional method of testing the development of critical thinking skills. This result is consistent with the studies of [26], [27], [20], but contradicts with the result of [20] study.

The researcher attributes the findings of the study to the novelty of the problem-based education strategy and the great importance of it in developing students' critical thinking skills by creating motivation and excitement for learning; Also, relying on problem-based learning strategy is also evidence of student positivity and his ability to build knowledge by themselves and consolidate knowledge requirements and develop the ability of students to employ his knowledge in new situations, which helps him to retain it and maintain its impact for the longest term.

\section{CONCLUSION}

Based on the results, the researcher presents the following conclusions:

1) A problem-based learning strategy contributes to developing critical thinking skills in the subject of science by enhancing the cognitive aspects of eighth-grade students.

2) The problem-based learning strategy contributed to the development of behavioral aspects such as commitment and time management. 
3) Female students in intermediate schools need to use more effective and practical educational programs according to their needs and problems, whether psychological, cognitive, or social.

\section{REFERENCES}

Mohamed, M. M. K. (2019). A proposed educational program based on brain-based learning in acquiring scientific concepts for science and the ability to solve problems for seventh-grade students. The Educational Journal, 59, 352-400.

Abd Rahman, M., Azmi, M. N. L., Binti Wahab, Z., bin Abdullah, A. T. H., \& Binti Azmi, N. J. (2016). The Impacts of problem-Based Learning'Approach in Enhancing Critical Thinking Skills to Teaching Literature. International Journal of Applied Linguistics and English Literature, 5(6), 249-258.

Anazifa, R. D., \& Djukri, D. (2017). Project-Based Learning and Problem-Based Learning: Are They Effective to Improve Student's Thinking Skills?. Jurnal Pendidikan IPA Indonesia, 6(2), 346-355.

Orozco, J. A., \& Yangco, R. T. (2016). Problem-based learning: effects on critical and creative thinking skills in biology. Asian Journal of Biology Education Vol, 9(3).

Suarniati, N. W., Hidayah, N., \& Handarini, D. (2018, July). The development of learning tools to improve students' critical thinking skills in vocational high school. In IOP Conference Series: Earth and Environmental Science (Vol. 175, pp. 1-7).

Ulger, K. (2018). The effect of problem-based learning on the creative thinking and critical thinking disposition of students in visual arts education. Interdisciplinary Journal of Problem-Based Learning, 12(1).

Wahyu, W., Kurnia, \& Eli, R. N. (2016, February). Using problem-based learning to improve students' creative thinking skills on water purification. In AIP Conference Proceedings (Vol. 1708, No. 1, p. 040008). AIP Publishing LLC.

Bashith, A., \& Amin, S. (2017). The effect of problem-based learning on EFL students' critical thinking skills and learning outcome. Al-Ta Lim Journal, 24(2), 93-102.

van der Vleuten, C. P., \& Schuwirth, L. W. (2019). Assessment in the context of problem-based learning. Advances in Health Sciences Education, 24(5), 903-914.

Davidson, N., \& Worsham, T. (1992). Enhancing thinking through cooperative learning. Teachers College Press, 1234 Amsterdam Avenue, New York, NY 10027.

Al Sulaiti, F., \& Mifdy, K. (2012). The Effect of the Strategies of Multiple-Intelligences and Six Hats Strategies and Problem-Solving in the Development of Eighth Grader's Scientific Thinking Skills in Jordan. Journal of Educational and Psychological Studies [JEPS], 6(1), 80-98.

Zirkani, M . (2017). The Effect of the Strategy of problem-based learning improves students' Scientific thinking skills. Lark Philosophy, Linguistics, and Social Sciences, 27, 489-511.

Piawa, C. Y. (2010). Building a test to assess creative and critical thinking simultaneously. Procedia-Social and Behavioral Sciences, 2(2), 551-559.

Strobel, J., \& Van Barneveld, A. (2009). When is PBL more effective? A meta-synthesis of meta-analyses comparing PBL to conventional classrooms. Interdisciplinary Journal of Problem-based Learning, 3(1), 44-58.

Hein, G. (1991). Constructivist learning theory. Institute for Inquiry. Available at:/http://www. exploratorium. edu/if/resources/constructivist learning. Html.

Ferreira, M. M., \& Trudel, A. R. (2012). The impact of problem-based learning (PBL) on student attitudes toward science, problem-solving skills, and sense of community in the classroom. Journal of classroom interaction, 23-30.

Paloloang, M. F. B. (2014). Penerapan model problem based learning (PBL) untuk meningkatkan hasil belajar siswa pada materi panjang garis singgung persekutuan dua lingkaran di kelas VIII SMP Negeri 19 Palu. Jurnal Elektronik Pendidikan Matematika Tadulako, 2(1).

Zabit, M. N. M. (2010). Problem-based learning on students' critical thinking skills in teaching business education in Malaysia: A literature review. American Journal of Business Education (AJBE), 3(6), 1932.

Wheatley, G. H. (1991). Constructivist perspectives on science and mathematics learning. Science education, 75(1), 9-21. 
Lapuz, A. M., \& Fulgencio, M. N. (2020). Improving the Critical Thinking Skills of Secondary School Students using Problem-Based Learning. Lapuz, AME, \& Fulgencio, MN (2020). Improving the Critical Thinking Skills of Secondary School Students using Problem-Based Learning. International Journal of Academic Multidisciplinary Research,(4), 1, 1-7.

Zhang, L. (2007). Promoting Critical Thinking, and Information Instruction in a Biochemistry Course, Issues in Science and Technology Librarianship. Retrieved December 1, 2008, from http://www.istl.org/07summer/refereed/html.

Florea, N. M., \& Hurjui, E. (2015). Critical thinking in elementary school children. Procedia-Social and behavioral sciences, 180, 565-572.

Sinprakob, S., \& Songkram, N. (2015). A proposed model of problem-based learning on social media in cooperation with the searching technique to enhance the critical thinking of undergraduate students. Procedia-Social and Behavioral Sciences, 174, 2027-2030.

Hussin, W. N. T. W., Harun, J., \& Shukor, N. A. (2019). Problem-based learning to enhance students' critical thinking skills via online tools. Asian Social Science, 15(1), 14-23.

Kronberg, J. R., \& Griffin, M. S. (2000). Analysis problems--A means to develop students' critical-thinking skills. Journal of College Science Teaching, 29(5), 348.

Hadi, A. (2013). Pengaruh pembelajaran problem based learning (PBL) terhadap kemampuan berpikir kritis dan pemahaman konsep biologi siswa SMA Negeri di kota Malang. SKRIPSI Jurusan Biologi-Fakultas MIPA UM.

Kurniawati, K. (2016). Pengaruh Model Project Based Learning (PjBL) Dan Problem Based Learning (PBL) Terhadap Kemampuan Berfikir Kreatif Siswa. Universitas Terbuka.

Özyurt, Ö. (2015). Examining the critical thinking dispositions and the problem-solving skills of computer engineering students. Eurasia Journal of Mathematics, Science and Technology Education, 11(2), 353361.

Sumarni, W., Wardani, S., Sudarmin, S., \& Gupitasari, D. N. (2016). Project-Based Learning (PBL) to improve psychomotor skills: A classroom action research. Jurnal Pendidikan IPA Indonesia, 5(2), 157-163. 